\title{
Е.В. Белогурова
}

Алтайский государственный университет

\section{Сны о «доме» в пьесе М. Булгакова «Бег»}

Аннотащия: В статье рассматриваются жанровые особенности пьесы Булгакова «Бег» как «драмы-эпопеи» и связанные с ними способы изображения драматической судьбы героев в ситуации утраты ими отечества и своего дома, суррогатами которого предстают временные убежища: церковь, станция, кабинет, дом на чужбине, - претерпевающие, в свою очередь, парадоксальные трансформации, обозначая в целом необратимый процесс разрушения традиционной русской культуры быта.

The paper deals with the genre peculiarities of the play «Flight» by M. Bulgakov as an «epic drama» and with the related methods of describing the characters' dramatic fate in the situation when they were deprived of their fatherland and homes and doomed to their surrogates like some temporary shelters such as church, station, office, house in a strange land. In their turn, they all undergo transformations, and frequently the transformations are paradoxical. On the whole, this signifies the irreversible destruction of the traditional Russian culture of every day life.

Ключевые слова: драма-эпопея, изгнание, сон, дом, церковь, кабинет, карусель.

Epic drama, expulsion, dream, house, church, office, carousel.

УДК: 821.161.1

Контактная информащия: Барнаул, ул. Димитрова 66. АлтГУ, кафедра русской и зарубежной литературы филологического факультета. E-mail: e.blgrv@mail.ru.

Авторская презентация новой пьесы М. Булгакова - «Восемь снов» - выдвигает на первый план установку на изображение внутреннего мира героев как начало эпическое, оставляя на втором плане собственно драматургическое определение «Пьеса в четырех действиях». Дробление действия на множество эпизодов, происходящих в разное время и разных местах, ставит под сомнение достоверность изображаемого события, придавая ему условный характер - «сны». Действие при таком частом членении более детализировано, драматург полнее выявляет мысли и чувства героев, их самовыражение.

Собирательный, коллективный образ субъекта сновидений в пьесе «Бег» отсылает к автору как медиатору и повествователю. Эпиграфы ко всей пьесе и к каждой картине - «сну» также актуализируют авторское начало, проявляющееся в творческой саморефлексии (автор «Белой гвардии», «Дней Турбиных», «Бега» - певец «во стане русских войнов»- переадресация на себя самопрезентации В. Жуковского в названии знаменитой баллады), в тематизации драматического действия: «покойся, кто свой кончил бег!...», «игла светит во сне...», «и множество разноплеменных людей вышли с ними » и др., - в субъектной форме эпиграфов: «мне снился монастырь», «сны мои становятся все тяжелее...». Кроме того, свобода масштабных перемещений в пространстве: Россия, Крым, Константинополь, Париж, - время действия, измеряемое годовым циклом, хрони- 
кальная эпизодическая композиция, наконец, водоворот исторических событий, вовлекающий в свою воронку судьбы людей, лишая их свободной воли - все это характеризует пьесу Булгакова не только как эпическую драму, но и как драмуэпопею. Ведущий в жанре эпопеи принцип универсализации бытовых реалий, «генерализации мелочей» в сочетании с изобразительно-речевой спецификой драмы и техникой сценической визуализации определяет особенности разработки темы Дома и Города в пьесе «Бег». «Бег», по мысли В.Е. Головчинер, обнажает индивидуально-личные аспекты человека в его взаимодействии с властью, с историей. Так, героями пьесы, отмечает исследователь, становятся люди, пережившие трагедию страны как личный опыт: «Это прежде всего люди военные, верные присяге, слову, долгу, это женщина для которой священны понятия семьи, дома. Именно она (Серафима, ищущая мужа - E.Б.) оказывается в центре действия, и в связи с ней представлены те, с кем свели ее крутые повороты истории» [Головчинер, 2007, с. 177].

Герои «Бега» - бездомные скитальцы, изгнанники, питающие смутную надежду обретения нового дома, где они могли бы закончить свой безумный бег и найти покой. Поэтому мотив Дома развертывается в образах памяти родного дома как невозвратного прошлого, чем обусловлены и эпическая дистанция, и универсализация домашнего быта в булгаковской драме-эпопее. В то же время фрагментарность сновидческого дискурса укрупняет детали пространственных изображений, усиливая их семиотическую напряженность.

Художественное пространство «Бега» разделено на две равные части: российская и заграничная. На своей «родной» российской территории герои оказываются в ситуации не только вне своего дома, но и вообе вне какого-либо жилого помещения. Последняя реплика, кроме значения «церкви» как места не для жилья, несет и другое значение слова, раскрывающее окончательное осознание приват-доцентом, добровольно покинувшим Петербург, потому что там стало «невозможно работать», что и его бег, и бег Серафимы за мужем - это не поиск лучшего места обитания, а спасение от неминуемой гибели. В этом смысле топос церкви реализует свои древние функции. Дом Бога, Крепость Бога на Руси в лихие времена был защитой для мирян от вражеского нашествия. Детализация интерьера монастырской церкви создает, действительно, образ убежища: монахи прячутся в подземелье, тьма внутреннего пространства едва освещается «свечками», в «неверном пламени» которых появляются сначала «конторка», «широкая скамейка», «окно, забранное решеткой», и только потом знаки священного места: лик святого, «полинявшие крылья серафимов», «золотые венцы». И «тьма», и «неверное пламя свечек», и «безотрадный октябрьский вечер с дождем и снегом» передают ощущение ненадежности убежища, обреченности самого святого места, обозначенных мотивами профанации, осквернения последнего в разработке мизансцены: монахи поют святые мотивы не перед алтарем, а в подземелье в «преисподней», тогда как под сводами божьего храма творится некое бесовское лицедейство: игуменское кресло занимает женщина - «Серафима в черной шубе» - по одному паспорту жена министра Корзухина, по другому - учительница Лошкарева; беременная женщина вдруг оборачивается генералом Чарнотой; под мещанским платьем некоего химика Махрова скрывается одетый в богатые ризы архиепископ Африкан. Причем, если лицедейство генерала передано драматургом в трагикомическом модусе, то в метаморфозе архиепископа явны ноты сатирического сарказма. Священник высшего церковного сана скрывается под фамилией «Махров». На вопрос красноармейца, что делает химик Махров во фронтовой полосе, тот отвечает: «Я продукты ездил покупать, огурчики...», что актуализирует этимон фамилии, значение которого по В. Далю, «мелочный торгаш», а в переносном смысле «махровый» - «ярко выраженное в отрицательном качестве явление» [Словарь русского языка, 1982, т. 2, с. 239]. Имя «Африкан», фамилия «Махров», звание «химик» (ассоциируется в данном контексте «алхимик», еретик) не- 
сут значение неправедности, отступничества, измены своему долгу подвижничества первосвященника русской церкви, что и констатирует игумен: «Пастырь, пастырь недостойный ... покинувший овцы свои!». Именно в этом разоренном, оскверненном, преданном владыкой Доме Божьем Голубков, по сути, тоже отрекшийся от своего отеческого дома, неожиданно для себя осознает неизмеримую ценность утраченного дома.

«Сон второй» более тяжелый, чем первый («сны становятся все тяжелее...»), так как место его действия все дальше от родного дома и вообще от дома как такового - это «неизвестная большая станция где-то в северной части Крыма» - все ближе к южной границе России. Железнодорожная станция - общее место в советских пьесах о революции и гражданской войне в 1920-е -30-е годы, что символизирует в «Беге», как и во многих пьесах этого периода, перепутье дорог, где сталкиваются армии и человеческие судьбы, место роковых встреч и разлук, последнего решительного выбора. Станция, занятая белыми штабными офицерами, скована «зверским непонятным морозом». Экспрессия эпитета «зверский» открывает тему зверских преступлений Хлудова и его контрразведки, а уже ставший постоянным эпитет «непонятный» развивает мотив сновидческой абсурдности происходящего. В белом мареве мороза, действительно, словно во сне, видна «стеклянная перегородка, в ней зеленая лампа» но не та домашняя, уютная, а «казенного типа» и в соседстве с двумя, тоже зелеными, похожими на глаза чудовищ огнями кондукторских фонарей.

Начавшаяся в первом «церковном» сне цепь измен и отречений здесь на последних рубежах России, на дорожном перепутье станции, затем в Севастополе, где происходит действие 3-го и 4-го «Снов», становится непрерывной, и самым слабым звеном перед смертельной опасностью оказывается то, что казалось самым прочным в мирном домашнем бытии людей - семейные узы и обязанности. Корзухин отрекается от молодой жены, едва на нее пало абсурдное подозрение в принадлежности к коммунистам; начальник станции, спасаясь от гнева «вешателя» Хлудова, выставляет перед собой, как щит, маленькую дочку, позднее в суматохе едва не потерянную им. Интеллигентнейший Голубков, испугавшись пытки иглой, которой угрожает ему офицер контрразведки, предает любимую женщину, подписывая, по сути, ей смертный приговор ложным утверждением, что она - коммунистка. И сами эти офицеры, изменяя своему долгу и чести, готовят подлый шантаж бывшему министру.

В этой атмосфере нравственного разложения, шкурничества, позорного бегства белой армии, Хлудова посещает воспоминание детства в родном доме, но не с его парадного входа - гостиных, залов, кабинетов, а с черного, заднего: кухня ночью, где царят тараканы, разбегающиеся при вспышке света и спасающиеся в мусорном ведре. Такими кухонными задворками России стал для белой армии, для беженцев обмороженный октябрьский Крым.

Последовательно обыгрывает Булгаков в «российской» части пьесы «кабинетный» мотив. Домашний кабинет в воспоминании Голубкова сменяется во втором «Сне» уродливым подобием штабного кабинета Хлудова, устроенного в станционном зале на месте «некогда бывшего буфета первого класса», словно предваряя «кухонные» воспоминания генерала. «Зверский» эпизод «Сна третьего» приобретает кошмарный характер, так как разыгрывается в «кабинете контрразведки», атмосфера и обстановка которого смутно напоминает уютные домашние кабинеты: «Какое-то грустное освещение», письменный стол, диван, шкаф, портьеры. За письменным столом офицер с фамилией «Тихий», соответствующей функциональной тишине этого места. Страшная метаморфоза кабинета в камеру пыток знаменует последние пределы падения бегущих тараканов - в мусорное ведро. Завершает российское действо еще одна кабинетная сцена. Самый роскошный кабинет ставки Главнокомандующего - во дворце, с камином - являет собой самый «странный вид»: «одна портьера на окне наполовину оборвана, на стене 
беловатое квадратное пятно на том месте, где была большая военная карта. На полу деревянный ящик...» [Булгаков, 1994, с. 105]. Беспорядок в кабинете, снятая со стены карта свидетельствуют о конце военных действий Белой армии и полном ее поражении, в связи с чем в диалоге Главнокомандующего с генералом Хлудовым сам дворец представляется мертвым домом: Но, независимо от желания Хлудова продумать эту мысль, пустой дворец внушает ему «беспокойство», заставляет «встать и открыть дверь», за которой «открывается анфилада темных и брошенных комнат с люстрами в темных кисейных мешках», напоминающих мешки повешенных на фонарях. Сознание Хлудова погружается в инобытие бреда сумасшедшего, преследуемого призраком повешенного солдата Крапилина. Для Голубкова в дворцовом кабинете открывается дверь на дорогу новых скитаний уже на чужбине в поисках Серафимы. На этой дороге он становится невольным спутником Хлудова, так что для них - «двух грешников» это еще и дорога искупления грехов в служении едва не погубленной ими женщине.

Необыкновенная карусель на площади Константинополя представляет собой суррогатную модель русского праздничного мира, знаменующего спасение русских беженцев от «красных комиссаров». Не случайно ее хозяин манифестирует тараканий аттракцион как «русскую придворную игру», «любимую забаву покойной императрицы в Царском селе». Так, этот химерический призрак царскосельских воспоминаний неотступно влечет бывшего генерала Чарноту, который, чтобы ощутить дух русского мира, «русской азартной игры» продает свой «лоток»последнее средство, обеспечивающее существование как его самого, так и опекаемых им Люськи и Серафимы. Именно здесь у кассы «карусели» Чарноту, «запорожца по происхождению», посещает исполненное щемящей ностальгии воспоминание о городах, покинутой Родины: «Господи! А Харьков! А Ростов! А Киев! Эх, Киев-город, красота, Марья Константиновна! Вот так Лавра пылает на горах, а Днепро, Днепро! Неописуемый воздух, неописуемый свет» [Там же, c. 115].

В «Сне шестом» действие перемещается с площадей и улиц Константинополя в жилой квартал, в домашнее пространство. Итак, «появляется двор с кипарисами, двухэтажный дом с галереей. Водоем у каменной стены» [Там же, с. 118]. Помимо экзотики (кипарисы, галерея, водоем, вдали балюстрада минарета) дом создает представление о достатке, надежности, защищенности его обитателей. Хозяева этого дома - греки, приютившие русских единоверцев, для которых - это не надежное жилище, а временное пристанище. Все действие картины развертывается не в доме, а во дворе, хотя содержанием этого действия являются шумные супружеские разборки между «холодной Люськой» и промотавшимся Чарнотой, интимные разоблачения, любовные признания Голубкова, позорный скандал с «греком-донжуаном».

Действие парижского «Сна» переносит зрителя вновь в «кабинет», Бывший министр торговли Корзухин в своем доме, в собственном особняке, обитает, в основном, в кабинете. Недаром при открытии занавеса, мы видим хозяина кабинета «в пижаме». Кабинет его, как и другие кабинеты в этой пьесе, тоже странный: обставлен он «необыкновенно изумительно», точно компенсируя невозвратную потерю министерского чина и кресла. Несмотря на претензии хозяина следовать европейскому стилю жизни, русский дух неистребим в его новом доме. Одетый по-французски и переименованный в «Антуана» лакей - русский лентяй Грищенко, не способный овладеть ни чужим языком, ни манерами. Русский дух выдает себя в безрассудной страсти Парамона Ильича к азартным играм, в чем он сходен с Чарнотой. Не случайно Люська - тоже натура русская и страстная, - спасаясь от холода и нищеты, предпочитает богатому титулованному «французу» своего соотечественника Корзухина.

Интерьер дома в последнем константинопольском «Сне» означает как будто окончательное отречение русского изгнанника от быта своего отечества и ада- 
птацию в чужой стране: «Комната в коврах, низенькие диваны, кальян. < ..> Хлудов сидит на ковре, поджав ноги по-турецки...». За «стеклянной стеной» - «константинопольский минарет, лавры» [Булгаков, 1994, с. 135]. Но призрак русского солдата и видимый за окном «верх Артуровой карусели» не дает покоя хозяину, напоминая о родине и о его реальном положении «кухонного таракана»: «Душный город! И это позорище - тараканьи бега» [Там же, с. 137]. Его бред томит и тревожит живущую под его опекой Серафиму, которой он обещал светлую комнату с видом на море, правда, «без особенного комфорта». Однако образ светлой комнаты на чужбине не обнадеживает Серафиму, ее манит открывшаяся возможность вернуться домой. С появлением Голубкова и Чарноты, когда все главные герои в сборе, ностальгический мотив доминирует, рождая в воспоминаниях героев образы родины: «Хлудов. Ты будешь тосковать Чарнота. / Чарнота. Эх, сказал. Я, брат, давно тоскую. Мучает меня Киев, помню я Лавру...» [Там же, с. 139]. И эта тоска, и эти воспоминания требуют от героев Булгакова последних решений в выборе своего места в мире. Генерал Хлудов, наконец, трезво и твердо осознавший, что в Россию ему - вешателю - путь заказан, а без России он жить не способен, покидает последнее свое пристанище, прихватив чемоданчик с револьвером, со словами «не таракан, в ведрах плавать не стану» [Там же, с. 138]. Генерал Чарнота не торопится в небытие и, пытаясь определиться в своем новом существовании, примеряет к себе романтические роли вечных скитальцев: «Кто я теперь? Я Вечный Жид отныне! Я - Летучий голландец!» [Там же, с. 140]. Но тут же, вполне осознавая свое ничтожное положение мелкого беса, называет себя «чертом собачьим», а последующее его действие снимает с представляемого им собственного образа и этот жалкий след инфернального героя, обозначая его место в балагане тараканьего царя Артура. Музыкальная тема этой финальной сцены - песня о Кудеяре-разбойнике, исполняемая русским хором на «тараканьих бегах» под российским флагом словно предлагает генералам-разбойникам православный путь покаяния, избывания своей вины перед родиной и своим народом в монашеском смирении и молитвах. В эту тему вплетается постоянный образ Киевской Лавры в воспоминаниях Чарноты. Голубков и Серафима, не зная греха перед Россией, выбирают путь на родину, в «Питер». Вместе с петербургской темой впервые возникает в памяти героев конкретный домашний адрес: «Серафима. <..> Я хочу опять на Караванную, я хочу опять увидеть снег!» [Там же, с. 140], - который придает реальность их иллюзорной надежде обретения родного дома.

\section{Литература}

Булгаков М.А. Пьесы 30 -х. годов. СПб., 1994.

Головчинер В.Е. Эпическая драма в русской литературе XX века. Томск, 2007.

Словарь русского языка: В 4-х т. / Под ред. А.П. Евгеньевой. М., 1981-1984. T. 2: K-O. 1982. 